\title{
Economic and Political Development of Africa and the EU
}

\author{
Abdullah Yuhannan ${ }^{1}$
}

\begin{abstract}
:
The EU, political and economic development in Africa is looks at the policies of European Union in respect to economics and politics in Africa. This study goes on to mention the main role of aid in the EU policy in shaping the economy and politics of Africa.

With so much received from the union comparing to the less that can be seen on ground, this paper investigate what went wrong and who are sole responsible for the mishap. The advent of China reshaping the policy of EU in Africa in discussed in this paper. In other to be in the realm of affairs the EU suggests a partnership with the Chinese who have already been in the process of aiding without strings and being totally mindful of their business.

The political class and their mismanagement is leading the continent into serious poverty and stagnated growth while the European remains quite and selective and meting out punishment to the offenders.
\end{abstract}

Keywords: Economic, Africa, Political development, Political Class

\footnotetext{
${ }^{1}$ Sakarya University, Middle East Institute, tonpanansatun@gmail.com
} 


\section{Introduction}

The debate still continues as to whether Africa as a continent still needs foreign aid or not. Nkrumah (1970) in his book, Neo-colonialism: the last stage of colonialism clearly stated that aid or foreign capital after independence is the 'colonial' masters' new method of colonizing Africa lands again. For him, foreign capital rather paves way for the exploitation rather than for development. Many are those who follow Nkrumah's line argument that Africa would see massive development provided it avoids aids that come from without Africa. Andrew Mwenda, sharing his view on TED talks puts forth the argument that Africa is not in need of any aid, however it is rather the media that make it look so. And out of the 53 countries in Africa political instability exists only in 6 nations. Aid, he recalls is one of the reasons Africa lacks self-initiative and also poverty reduction schemes implemented the Western countries are rather geared towards treating 'symptoms' instead of causes of African economic problem.

Mangomana Trymore of CNN rather opines that it governments of Africa have been eager receivers rather than clearheaded managers of Western generosity. This point rather takes the argument to another level which is the issue of misgovernance in Africa. Mangomana Trymore also writes that a class of scholars advocate for the total removal of all forms of foreign aid to sub-Saharan Africa. He argued that more than US\$1 trillion that has been given to the region over the last 60 years has not changed anything.

Meanwhile some others have been on the side of the argument that aid in Africa has really helped decrease poverty, disease and have helped support businesses and trades as well as education in Africa. The World Bank for instance reports in, Assessing aid, that from 1998-2008 economic growth accelerated to about 6 percent because aids to Africa was increasing as well. Within that period HIV and poverty was in decline whereas human development and rates of primary completion rates were improving. Proponents of aid to Africa have always maintained that Africa as a continent needs aid. Some have even gone ahead to say that the aid to African should rather increase as against the notion of the opponents that aid must cease.

Our main point of discussion is not about whether Africa needs aid or not. This article rather aims at discussing the aids the continent has taken and its impact towards its economic and political development. Whether it is agreed upon or not Africa still remains the continent to have received heaps of aid from several international organizations and individual philanthropists worldwide with Subsaharan Africa receiving most of the donation. Several bodies like UN, EU and even the Arab unions have contributed to the development of Africa. Individual countries like the United States of America and Britain among other have also been giving aid to African countries (Olaniyan, 1996). 
This paper however is much interested in the aid that came from the EU to Africa. Kerem Gumus (2011) writes in his article that Europe Union became involved in Africa due two main reasons. The first is the fact that EU is one of the most prosperous regions in the world with enough resources to give aid and support to African countries. The second reason is due to colonial history that has forged cultural and diplomatic ties between the region and the African continent. France and Britain have always been pouring aids to Africa especially the West Africa even before the EU strategy for Africa was agreed at the UN. In recent times, during the outbreak of Ebola Virus, the European Union, with its Member States, donated close to $€ 2$ billion in financial aid to help them battle, contain and recover from the outbreak in West Africa. Since March 2014, the European Commission has provided close to $€ 70$ million in humanitarian aid to address the most urgent needs. These funds have been channeled through humanitarian partner organizations, including the UN, International organizations and NGOs. EU humanitarian aid has contributed to epidemic surveillance, diagnostics, treatment and medical supplies; deployment of doctors and nurses and training of health workers; awareness raising among the population and promotion of safe burials" (ECHO-Factsheet, 2016).

This aid provided by the Union during Ebola scare ranges from humanitarian, development and early recovery aid as well as medical research assistance. It is largely due to the gross aid and supports by the European Union that new Ebola cases, in recent times, haven't been reported. Looking at the continuous support Africa gets from the EU the argument that Africa doesn't need aid or it has overgrown aid becomes weak and irrelevant because the aid keeps on going to that continent. However several under development and stunted growth recorded in many countries in Africa despite the large donations they have received raises question on whether the aid is helping the continent or not. Economically, poverty and lack of jobs is still high and same can be said about politics too in Africa. Despite the slow or stunted growth recorded in the continent, it cannot be denied that some other countries have recorded steady development, recovery from poverty and myriad of crises with the aid. The fact however remains that less is achieved with this aid than would be expected.

\section{Economic Development and EU}

Whatiseconomics.org quotes Professor Michael Todaro's definition as an increase in living conditions, improvement of the citizens' self-esteem needs and free and a just society. Todaro suggests that the most accurate method of measuring economic development is the Human Development Index which takes into account the literacy rates \& life expectancy which in-turn has an outright impact on productivity and could lead to Economic Growth. Maryanin Feldman et al. (2015), mention Schumpeter's view, of economic development as a fundamental transformation of an economy that includes altering the structure of the industry, the characteristics of education and occupation of the population, and the entire social and institutional fabric. 
The two explanations given for economic development seek to establish that economic development in a nutshell is the rise of living condition as well as the improvement of the social and institutional fabric of the population. By this meaning an average person life must be able to have food, clothing, shelter, and some sort of safety and access to clean water as well. It is the primary duty of every responsible government in every part of the world to assist citizens and nationals achieve those needs. It is when these needs are met at an affordable price and conditions that experts refer to as a good standard of living is realized. To a larger extent when the system in the country becomes conducive for citizens to be employed and businesses see growth, that country's economy is basically referred to as a good one.

Africa is the second largest continent and world's most poor continent. In subSaharan Africa for instance more than 218 million people live in abject poverty. The EU has consistently among other international bodies provided financial aid and economic recovery programs to Africa. In 2009, for instance, the EU announced US $\$ 22.5$ million in economic aid to the government of Togo (Gumus, 2011). Recently according to the European commission press release of July 6th, 2015, signed by Commissioner Neven Mimica (Commissioner for International Cooperation and development), and cosigned by President Kadire Desire (ECOWAS President) and President Hadjibou Soumare (UEMOA President), the EU begins new regional funding for cooperation that covers the time until 2020. The program which amounts to a total $€ 1.15$ billion focuses on three areas of cooperation; peace, security and regional stability, regional economic integration and trade, and sustainable development of natural resources and biodiversity. And to help boost the trade industry besides the huge sums of financial support for the continent trade strategies were put in place as well. According to ec.europa.eu, EU's largest trading partner in Sub-Saharan Africa is West Africa. To help boost the trade, the EU remains loyal to West Africa as the biggest trading partner by supplies a large part of the equipment that contributes to economic growth and development in the region and is the main export market for West African agricultural and fisheries products. The fact is that West Africa for some time now has been the most important investment destination for the EU in Africa.

Looking at the above aid and so many others unmentioned, the continent is supposed reduced the rate of poverty drastically if not say a good bye it. Apart from gross mismanagement of all the financial aid and serious corruption that hinder the economic development of Africa, Dambisa Moyo writes in her book, Dead Aid: why aid is not working..., criticizing the rate at which African countries have taken aid and yet no palpable growth is realized. To her, aid has done much harm to African countries since it has been an "unmitigated political, economic and humanitarian disaster" (Moyo, 2009). Again re explaining her stand against foreign aid, Moyo in Wall Street Journal, mention that even though she isn't totally against humanitarian aid, she is yet to come to terms with the claim that charity based aid can provide long term sustainable development in Africa. Manasi Sharma writing on, Is Foreign Aid Helping or Hurting Africa, at globalenvision.com quotes Jammie Drummond, 
Madelein Bunting and few other people condemning the work of Moyo as poorly argued.

A lot more others like Mangomana Trymore, Andrew Mwenda and Caldirisi share Moyo's view that aid hasn't really reflected its purpose in Africa, rather it has worsen the situation. She rather opts for a trade, foreign investments and microfinance opportunities as better way of helping Africa economically since the $\$ 60$ trillion for the past 60 years hasn't been able to solve anything in Africa. If what Moyo talks about is increase in trade between Africa and EU her point of view could have been defendable because the EU already is the largest trading partner of Africa. The main problem the trade partnership faces in the influx of Chinese trade in the continent "While the EU is still Africa's largest trading partner, with a share of the total African trade twice as high as China's, this share fell by more than a fifth in the last 10 years, while the Chinese share increased by over $160 \%$ during the same period" (The EU and Africa: Valletta and Beyond, 2015).

\section{Political Development and EU}

Lucian Pye in his article mentions several definition of political development. Among the definitions Pye mentions the definition of political development as the political pre requisite of economic development and another as the building of democracy. In the article that contains about ten different definition of political development, he mentions another definition as stability and orderly change. By democracy building the definition seeks to mention democratic institution. In general political development can be looked at as a good political system that will ensure equality, capacity, and differentiation as the center of development process. By that understanding, a country that cannot provide such is considered as politically undeveloped nation.

Europal.europa.eu a website of the EU has it that Euro-African relations are governed by partially overlapping policy with Cotonou Agreement (2000) and the Joint Africa-EU strategy (JAES) as most important of them. The framework includes political, development and economic dimensions. The two policies among others mention political dimension. In this regard the EU has contributed much strength to the African region in terms of aims of peace and how to specifically achieve it. In trying to keep peace and ensure good political help the EU has maintained a military distance from Africa (Gumus, 2011). In the case of Sudan and the Democratic Republic of Congo, they would have sent troops in at least in of the country, however they declined to avoid a kind of development that they have attempted to avoid looking at the way the conflict was. However, years later the EU contributes military too. "The EU already contributes actively to bringing peace and security in Africa: out of the 34 CSDP missions launched 18 have been deployed or are ongoing in Africa, including the most expensive military operation of the EU so far, NAVFOR ATALANTA, off the coast of Somalia" (The EU and Africa: Valletta and Beyond, 2015). 
The connection between peace and stability and development was demonstrated clearly in the Africa Strategy adopted in 2005. According to the strategy, 'Without peace, there can be no lasting development' (Africa Strategy, 2005)

\section{Assessing the Economic and Political Development}

It is remarkable how the debate on EU involvement in conflict prevention with special emphasis on Africa developed from the early 1990s. It was a topic at the EU summit in Madrid in 1995 and it was included in Article 11 in the Cotonou agreement from 2000 under the headline 'Peace-building policies, conflict prevention and resolution'. Following the signing of the Cotonou Agreement, a number of policy statements emphasized that development policy and co-operation programs are the most powerful instruments when the Community wants to treat the causes of conflict" (Olsen, 2008). The Cotonou agreement stresses on human rights, democracy and the rule of law as very crucial elements partner nations should strictly adhere to. It implies also that the violation of any can lead to suspension of aid. The can impose sanction two different folds. It can either impose autonomous sanction or implement decided sanctions by UN Security Council. These sanctions generally entail arms embargos funds freezing or banning of officials from travelling.

Agreements are made to follow and abide. However the EU in its political dispensation dealing with Africa does not seem to be consistent. The number of exemptions to sanctions applied, brought in inconsistency in terms of policy enforcement. The president of Zimbabwe for instance, Robert Mugabe was invited by the then French leader to attend the 2003 France-Africa Summit though he was sanctioned by the EU, which included a travel ban for President Mugabe. Not very long ago, the EU agreed to lift the travel ban temporary to allow the Mugabe participate in the EU-Africa summit in 2007 and that nearly led to boycott the summit due pressure mounted on the union (Brummer, 2009). In addition to that also it has been pointed out that the EU's normative rhetoric serve its own strategic interests only. Specialists of development refer to that as a problem of inconsistency of European development policy, where specific foreign policy objectives in the area of security (Youngs 2004).

One big challenge to the EU and trade in Africa is the influx of Chinese aid and trade module. The Chinese aid policy in Africa is not a string attached aid. Chinese leaders seem not to believe in conditionality and sanctions as a tool for foreign policy. This could be explained by the fact that much of Chinese aid policy in Africa is inspired by its own experience, marked by the American embargo imposed after the creation of the PRC. The EU seems to realize that in order to compete with the Chinese and remain a relevant actor in Africa, it needs to adjust its development approach and turn it into a more reasonable and partnership-based strategy. European policy makers seem to start adopting a more pragmatic approach as a response to this dilemma. In that regard, Par Sarah Grauls \& Anna Stahl mention 
Philippe Maystadt, European Investment Bank president, mentioned that the EU needs to think about the degree of conditionality it needs to apply, in order to prevent "excessive" conditionality. He expresses his worry that African states might turn to other sources of financing without such strings attached to it if the conditions are not set at a realistic level.

The EU may have tried and futility to suppress the China Africa relations in trade and aid in general. The European show willingness to move on this issue is the recent initiative of establishing a "trilateral EU, Africa and China cooperation" (European Commission, 2008). China is not suppressing the influence of EU in Africa rather represents an opportunity for it to review its current approach to development cooperation in Africa. China's increasing involvement reflects a changing environment to which the EU needs to adapt its development policy if it wishes to maintain its strong presence on the African continent.

\section{Conclusion}

The EU throughout its policies has shown some kind of support that seems very attractive to the African continent. A continent with a population set to double up to 2.4 billion by 2050 , up until now the money, support the continent has taken and the less progress that can be witnessed in it only indicate that the EU aid should indeed take a different dimension. One of the good ways to make things better, as a proponent of no string attached aid, is the joint policy between EU, China and Africa since the Chinese presence contributes to current variations in the European development policy.

For more than decades the debate continues as to whether aid is hurting or building Africa. For the records Africa is just taking more aid than it used to need. The point therefore rather is not whether the continent should be given aid or not. It is also not the issue of which kind of aid should be given to the continent or not. The issue is rather on how to handle that large but a bit hurting aid with some kind of strings attached to it. Moyo got it right on the issue of corruption and misgovernance that leads to the embezzlement of the public aid by the political class in Africa. She reserves that those aids has been pocketed by corrupt politicians. Professor Walter E. Williams, opines that foreign aid provides the financial resources that enable Africa's corrupt and inept regimes to buy military equipment, pay off their cronies and continue to oppress their nationals. Also it provides resources for leaders to live extravagantly and set up "retirement" accounts in foreign banks.

Journalist Michael Maren as written in www.fee.org, reports that for ten years before the famine of 1992, Somalia was the largest recipient of aid in sub-Saharan Africa, however that most of the funds were vanished in the corrupt maze of the Somali government's nepotistic bureaucracy. For instance Italy alone from 1981 to 1990 , sent over $\$ 1$ billion to fund projects in Somalia even though the regime was slaying 
its opponents. It was not surprising when the New African Yearbook called Somalia "the Graveyard of Aid. Africa need aid but need to learn to use the aid wisely.

\section{References:}

Africa: Leveraging the Crisis into a Development Takeoff. Retrieved from http://www.researchgate.net/publication/227641144_Africa_Leveraging_the_ Crisis_into_a_Development_Takeoff.

Aid Has Failed to End Poverty in Sub-Saharan Africa: Case Study. Retrieved from http://www.magomana.com/index.php/en/magomana-research/item/94-aidhas-failed-to-end-poverty-in-sub-saharan-africa-case-study-data-paints-ableak-picture-of-aid-projects-in-the-region.html.

Andrew Mwenda|Speaker|TED.com. Retrieved from http://www.ted.com/speakers/andrew_mwenda.

Carbone, M. 2013. Between EU actorness and aid effectiveness: The logics of EU aid to Sub-Saharan Africa. International Relations, 27(3), 341-355, doi:10.1177/0047117813497300.

EU support to the region of West Africa reaches $€ 1.1$ billion. Retrieved from http://europa.eu/rapid/press-release_IP-15-5309_en.htm

Feldman, M., Hadjimichael, T., Lanahan, L. \& Kemeny, T. 2015. The logic of economic development: A definition and model for investment. Environment and Planning C: Government and Policy, 34(1), 5-21, doi:10.1177/0263774x15614653.

Lancaster, C. 1999. Aid effectiveness in Africa: The unfinished agenda. Journal of African Economies, 8(4), 487-503, doi:10.1093/jae/8.4.487.

Moyo, D. 2010. Dead aid: Why aid makes things worse and how there is another way for Africa. London: Penguin Books.

Nkrumah, K. 1970. Neo-colonialism: The last stage of imperialism. London, Panaf.

Olaniyan, R.O. 1996. Foreign aid, self-reliance, and economic development in West Africa. Westport, CT, Praeger.

Why foreign aid and Africa don't mix - CNN.com. Retrieved from http://www.cnn.com/2010/OPINION/08/12/africa.aid.calderisi/index.html

Brummer, K. 2009. Imposing Sanctions: The Not So 'Normative Power Europe. European Foreign Affairs Review, 14(2), 191-207.

Youngs, R. 2004. Normative Dynamics and Strategic Interests in the EU's External Identity. Journal of Common Market Studies, 42(2).

BBC World Service | Focus On Africa | Ghana is free forever. Retrieved from http://www.bbc.co.uk/worldservice/focusonafrica/news/story/2007/02/070129 _ ghana50_independence_speech.shtml.

European Commission, Press release. Retrieved from http://europa.eu/rapid/pressrelease_MEMO-11-351_en.htm.

European development policy towards sub-Saharan Africa. Retrieved from https://sites.google.com/a/revue-emulations.net/www/archives/n7/grauls.

Fourth EU-Africa summit - European External Action Service. Retrieved from http://eeas.europa.eu/africa/. 
Key facts on the Joint Africa-EU Strategy - Europa. Retrieved from http://europa.eu/rapid/press-release_MEMO-13-367_en.htm.

The Africa-EU Strategic Partnership - European Commission. Retrieved from http://ec.europa.eu/education/international-cooperation/africa_en.htm.

The Sorry Record of Foreign Aid in Africa. Retrieved from https://fee.org/articles/the-sorry-record-of-foreign-aid-in-africa/.

Why Foreign Aid Is Hurting Africa - WSJ - The Wall Street. Retrieved from http://www.wsj.com/articles/SB123758895999200083.

Woods, D. 2005. The shifting politics of foreign aid. International Affairs, 81(2).

Haastrup, T. Africa-EU Partnership on Peace and Security. Africa and the European Union, doi:10.1057/9781137269478.0009.

Is the EU Model Conducive to Helping Africa? A Critical. Retrieved from http://i11.cgpublisher.com/proposals/295/index_html.

Larsson, T. \& Trondal, J. 2010. Agenda Setting in the European Commission: How the European Commission Structure and Influence the EU Agenda. EU Administrative Governance, doi:10.4337/9781845429966.00010.

Mangala, J. 2006. Africa-EU Strategic Partnership. Africa and the European Union, doi:10.1057/9781137269478.0006. 